\title{
Realizm polityczny Romana Dmowskiego
}

KATARZYNA IWONA FLAGA - doktorantka na kierunku Nauki o polityce w Instytucie Nauk Politycznych i Stosunków Międzynarodowych Uniwersytetu Jagiellońskiego. Absolwentka politologii (specjalność instytucje i zarządzanie polityką) oraz administracji na UJ. Autorka artykułów i redaktorka monografii naukowych, organizatorka międzynarodowych konferencji narodowych, działaczka Towarzystwa Doktorantów UJ. Przygotowuje rozprawę doktorską dotyczącą filozofii Ayn Rand. Zainteresowania badawcze: myśli polityczna, liberalizm, libertarianizm, filozofia nauki. 
Spory o Rzeczpospolita. Przeglad wybranych dyskusji politycznych $i$ ustrojowych w ostatnim stuleciu, red. P. Gofron, A. Matuła, A. Paderewska, Kraków 2020, s. 104-117.

Dostać Romana Dmowskiego oraz poglądy polityczne stanowiły 1 już w czasach jego działalności temat godny rozważań. Studiując opublikowane przez polityka i myśliciela pozycje, niejednokrotnie podejmuje się rozważania, przez pryzmat którego paradygmatu go badać. Chociaż realizm, jako pespektywa teoretyczna, przestał być dominującym narzędziem w sferze stosunków międzynarodowych, warto zgodnie z jego założeniami pochylić się nad działalnością współzałożyciela Narodowej Demokracji. Był on bowiem politykiem o wielu twarzach, rozumiejącym rzeczywistość polityczną jako grę interesów, świadczącą o dojrzałości narodu ${ }^{1}$.

Niniejsze rozważania zostaną podzielone na dwie części. Pierwsza z nich będzie zorientowana na zdefiniowanie podstawowych założeń realizmu politycznego, które następnie, w części drugiej, zostaną odniesione do poglądów Romana Dmowskiego.

W związku ze specyfiką polskiej sceny politycznej, w poniższych rozważaniach realizm nie będzie przedstawiany jako alternatywa dla idealizmu czy utopizmu, jak czyni to amerykańska szkoła, lecz jako alternatywa dla romantyzmu politycznego ${ }^{2}$. Romantyzm polityczny jest bowiem postawą i wzorem postępowania niezwykle często występującą w polskiej historii.

Założenia realizmu to przede wszystkim empiryzm, specyficzna wizja jednostki, propagowanie określonych postaw wśród ludzi, okre-

I Por. K. Kawalec, Roman Dmowski. Biografia, Poznań 2016.

2 P. Kimla, Historycy-politycy jako źródto realizmu politycznego, Kraków 2009. 
ślona moralność, etyka odpowiedzialności za skutki oraz szcczególna rola siły państwa w relacjach międzynarodowych, a także interesu narodowego. Pod kątem tych narzędzi badawczych zaprezentowana zostanie korelacja paradygmatu realizmu z myślą i działalnością Romana Dmowskiego. Ze względu na szeroką twórczość autora Naszego patriotyzmu, analiza dotyczyć będzie wyłącznie okresu pomiędzy I893 a I9I8 rokiem. Przeglądowi poddany zostanie zatem okres sprzed odzyskania niepodległości przez państwo polskie. W związku z ogromną ilością dzieł Romana Dmowskiego, artykuł będzie się opierać na poglądach, przedstawionych w jego trzech głównych pozycjach: Nasz patriotyzm (1893), Myśli nowoczesnego Polaka (1903) oraz Niemcy, Rosja i kwestia Polska (1908).

\section{Realizm polityczny - założenia}

Realizm polityczny jako paradygmat oraz narzędzie badawcze, należy definiować na podstawie myśli Hansa Morgenthaua³, Johna Mearsheimera ${ }^{4}$ oraz Piotra Kimlis ${ }^{5}$. Analiza pozwala na wyodrębnienie kilku elementów, składających się na pojęcie realizmu oraz stanowiących perspektywę badawczą. Zostały one wymienione we wstępie rozważań.

Empiryzm odnosi się do osadzenia analizy politycznej w faktach oraz nakazuje zwrócenie uwagi na dotychczasową historię ${ }^{6}$. Bieg dziejów danej społeczności, a także analiza działalności czynnych polityków stanowią bowiem podstawę realistycznej interpretacji świata. Cechami szczególnymi pozostaje zatem odejście od normatywizmu, fachowość oraz przywiązanie do wysokich kompetencji w sferze poli-

3 H. J. Morgenthau, Polityka między narodami. Walka o potęge i pokój, przeł. R. Włoch, Warszawa 20 Io.

4 J. Mearsheimer, The tragedy of great power politics, Londyn $200 \mathrm{I}$.

5 P. Kimla, Historycy-politycy jako źródto realizmu politycznego, dz. cyt.

6 P. Kimla, Historycy-politycy jako źródto realizmu politycznego, dz. cyt., s. 65-70. 
tycznej. Realizm jest bezstronną oceną rzeczywistości. Każde świadome zachowanie w sferze politycznej powinno opierać się na precyzyjnym przeglądzie faktów i racji. Założenie empiryzmu nakazuje polityczny egzystencjalizm, umożliwiający przyjmowanie i analizowanie faktów bez symbolizmu i emocjonalizmu. Aposterioryczność prawdy, wymóg empiryczności oraz istotność historii i czystych wydarzeń politycznych stanowi fundament realizmu.

Człowiek w realizmie jest uznany za jednostkę omylną, którą w karbach utrzymuje wypracowany systemem instytucjonalny, szeroko rozumiany. Badanie jednostek powinno odbywać się poprzez odniesienie się do warunków i realnego świata, w którym żyją. Elementem realizmu jest także przyglądanie się ludziom w sytuacja kryzysowych, kiedy stabilny grunt zostaje im odebrany ${ }^{7}$. Pozwala to na poznanie tego, co tkwi w każdym z nas. Człowiek jest zatem pomyślany jako stworzenie o brutalnej naturze, dostosowujące się do warunków poprzez instytucje, gdyż zdaniem myślicieli realistycznych stan natury nie został ostatecznie przezwyciężony. Pesymizm antropologiczny jest odnoszony do zasady prezentowanej przez Thomasa Hobbesa ${ }^{8}$, Niccolò Machiavellego ${ }^{9}$ czy Davida Hume’ ${ }^{\text {Io }}$, zgodnie z którą człowiek postępuje dobrze i właściwie tylko wówczas, gdy system nie daje mu innej możliwości. Idąc tym tokiem myślenia, racjonalność człowieka oznacza podporządkowanie się prawu i instytucjom. Wymagana jest oczywiście kontrola, która pozwala na zapanowanie nad deprawowaniem jednostek ze strony mniej racjonalnych ludzi ${ }^{\text {II }}$ Wynika z powyższego,

7 P. Kimla, Historycy-politycy jako źródto realizmu politycznego, dz. cyt., s. Io9I 6 .

8 Zob. T. Hobbes, Lewiatan, czyli materia, forma i wtadza państwa kościelnego i świeckiego, przeł. Cz. Znamierowski, Warszawa 1954.

9 Zob. N. Machiavelli, Wybór pism, przeł. J. Gałuszka i in., Warszawa 1972.

Io D. Hume, Badania dotyczące rozumu ludzkiego, przeł. J. Łukasiewicz, K. Twardowski, Warszawa $200 \mathrm{I}$.

I I P. Kimla, Historycy-politycy jako źródto realizmu politycznego, dz. cyt., s. I07I 22 . 
że władza jest zjawiskiem niezbędnym, a polityka ma stanowić system wytwarzania dobrej woli, budowany przez siły społeczne. Pozwala to na stwierdzenie, że egzekwowanie prawa i porządkowanie panującym regułom jest istotniejsze niż realizacja poczucia sprawiedliwości i słuszności. Realizm zakłada bowiem balast emocjonalny - ludzkie troski, niepokoje i strach.

Za tak skonstruowaną wizją jednostki, idzie preferowanie określonych postaw działania ${ }^{12}$. Przede wszystkim jest to priorytet oszczędności, odnoszący się do wszystkich sfer życia. Oszczędność polega na ograniczeniu wszelkich możliwych nakładów do minimum. Jako że realizm jest typowy dla kultury kupieckiej i mieszczańskiej, charakteryzuje się szacunkiem do posiadania rzeczy materialnych. Istotne jest, że paradygmat ten nie narzuca szlachetności, dydaktyzmu, homiletyki, normatywizmu i komunikacji w zdaniach powinnościowych. Ocenie podlegają działania i postawy, a zasadniczym pytaniem pozostaje to, jak wygląda nasza rzeczywistość, a nie jak powinna ona wyglądać. Nie oznacza to jedna, że etyka jest odseparowana od polityka. Jest jej ważnym elementem, jednakże należy w niej usunąć moralizatorstwo oraz zjawisko kryminalizowania wroga. Najwyższym imperatywem jest odpowiedzialność za skutki - ich właściwa kalkulacja i ponoszenie ciężarów podjętych decyzji. W etyce przekłada się to na postulat dalekowzroczności, dostrzegania granic działania, dążenia do kompromisu. Ponadto zasady moralne powinny być odczytywane w konkretnych okolicznościach miejsca i czasu, a nie stosowane bezpośrednio i bezrefleksyjnie. Realizm dostrzega bowiem napięcie pomiędzy zasadami moralnymi a wymogiem osiągania sukcesów politycznych ${ }^{13}$. W sferze polityki zatem przywódca powinien kierować się tylko interesem własnego państwa. Rola moralności pozostaje zatem ograniczona

I 2 P. Kimla, Historycy-politycy jako źródto realizmu politycznego, dz. cyt., s. I03I09.

I 3 H. J. Morgenthau, Polityka między narodami. Walka o potęge i pokój, przeł. R. Włoch, Warszawa 20 ı. 
w stosunkach między państwami. Motywacje i ideologiczne wybory nie są kryteriami oceny działań w sferze publicznej. Polityka stanowi bowiem autonomiczną dziedzinę nauki, gdzie istotne są skutki działania. Powoduje to, że ideał dobra i prawdy nie może stanowić źródła walki na śmierć i życie. Ważniejszy pozostaje pokój i instynkt przetrwania. W ramach omawianej odpowiedzialności za skutki, należy dodać, że państwa są skłonne zaniechać konfliktów w obawie przed odwetem i jego konsekwencjami. Powoduje to realizowanie zasad obiektywizmu i bezstronności ${ }^{\mathrm{I}}$.

Etyka wpływa zatem w sposób niezwykle istotny na funkcjonowanie państwa w stosunkach międzynarodowych. W nich bowiem prymat wiedzie jako główny podmiot właśnie zinstytucjonalizowane państwo. Pełni rolę gracza politycznego w systemie anarchicznym. Zasadniczym założeniem jest przyjęcie, że w relacjach nie można przewidzieć intencji i tendencji poszczególnych członków systemu. W związku z tym państwa obawiają się siebie nawzajem, pozostając racjonalnymi graczami. W taki sposób też kalkulują swoje możliwości i interesy ${ }^{15}$. Celem fundamentalnym państwa jest przetrwanie i poszukiwanie siły, nie tylko w wymiarze realnej siły zbrojnej, ale także siły jako kapitału wszelkiego rodzaju i możliwości. Istotne jest, że państwo posiada potencjał ofensywny, gwarantujący mu bezpieczeństwo. Kategoria siły oparta jest na rozumieniu pozytywnym jako możliwości ochrony, arbitrażu czy neutralizacji konfliktów. Stanowi wartość wędrującą i tworzywo działań politycznych. Polityka staje się zatem analizą bioracą za podstawę pomiar siły poszczególnych graczy międzynarodowych, których celem pozostaje realizacja interesu narodowego przez elity suwerennych państw. Jednakże nieuchronne jest występowanie zjawiska antagonizmów między państwami w związku z ograniczonym dostępem do dóbr. Rozwiązaniem problemu jest ciągłe dążenie do zachowania równowagi sił bez względu na zmieniający się kontekst kulturowy

I 4 P. Kimla, Historycy-politycy jako źródto realizmu politycznego, dz. cyt., s. 7 I-78.

I 5 H. J. Morgenthau, Polityka między narodami..., dz. cyt. 
i polityczny interesów. Winny one być zatem kontrolowane. Realizm zakłada tu determinizm przyczynowy i teleologiczny.

Przedstawiony powyżej model realizmu, pozwoli na odniesienie się do przemyśleń Romana Dmowskiego.

\section{Roman Dmowski - realista}

W rozważaniach na temat przemyśleń Romana Dmowskiego uwaga zostanie skupiona wyłącznie na okresie zaborów w Polsce. W związku z tym ze szczególną skrupulatnością zostaną przeanalizowane trzy wymienione we wstępie dzieła myśliciela. Należy podkreślić, że działacz skupiał swoją uwagę na prezetowaniu poglądów dotyczących wizji Polski, jej miejsca w Europie oraz płynących z tego konsekwencji. Jego podejście było powielane przez całe środowisko skupione wokół endecji ${ }^{16}$.

Zaprezentował także nowoczesny sposób myślenia o działaniach powstańczych $^{17}$. W wydanym w I893 roku Naszym patriotyzmie współzałożyciel Narodowej Demokracji zwraca uwagę na konieczność zerwania $\mathrm{z}$ programem powstańczym ${ }^{\mathrm{I}}$. Polityk twierdził, że $\mathrm{w}$ miejsce $\mathrm{z}$ góry skazanych na klęskę zrywów narodowych, należy wprowadzić działania, mające na celu wzmocnienie sił narodu. Zwracał uwagę, iż mechanizm buntów powstańczych jest kosztowny i pozwala „najcenniejszą krew upuszczać sobie strumieniami”»`. Widać tu zarówno postulat wypracowywania potencjału oraz wprowadzenia zasady oszczędności. Krytyka powstań stanowi odejście od romantyzmu politycznego i wskazuje na konieczność utrzymywania tego, co dobrze, jako naród, posiadamy.

I6 K. Kawalec, Spadkobiercy niepokornych: dzieje polskiej myśli politycznej I9I8-1939, Wrocław 2000, s. Io8.

I7 Por. K. Kawalec, Roman Dmowski..., dz. cyt.

I 8 R. Dmowski, Nasz patriotyzm, w: R. Dmowski, Wybór pism, wybór i wstęp

R. Wapiński, Warszawa ı990, s. 56.

I9 R. Dmowski, Nasz patriotyzm, dz. cyt., s. 56. 
W ramach założenia odpowiedzialności, Roman Dmowski podkreśla, że nie należy wysyłać ludności (istotnego kapitału) na pewną śmierć.

W kolejnym fragmencie autor Przewrotu zaznacza, że polityka narodowa, w głównych swoich zasadach, musi być ogólnopolska ${ }^{20}$. Oznacza to, że winna łączyć ludzi z trzech zaborów i uświadamiać o wspólnocie celów. Czyn polityczny Polaka bez względu na to, gdzie jest dokonywany i przeciw komu skierowany, musi mieć na widoku interesy całego narodu. Dostrzegamy tu podporządkowanie działań interesowi narodowemu oraz osadzenie jednostki w konkretnej czasoprzestrzeni wraz ze spoglądaniem na aktualną sytuację.

Myśliciel dokonał także wnikliwej krytyki polityki poszczególnych grup społecznych. Dla wywodu istotna jest analiza polityki biernego oporu $^{21}$. Zauważone zostaje poprzestawanie na tym, co już zostało osiągnięte lub co udało się utrzymać, bez czynnego aktu walki i realizacji wyznaczanych celów. Błędem jest przypisywanie wielkiej wagi tym prawom i instytucjom, które funkcjonują. Cel należy pokładać w realizowaniu nowych zadań. Dmowski zwrócił także uwagę na socjalizm²2. Uznał go za pożądany ze względu na wzrost siły klasy robotniczej, lecz dostrzegał w nim jednocześnie brak aspektu praktycznego. Potwierdza to zatem założenie konieczności rozwoju, prezentowane przez realizm oraz wskazuje na priorytet wytwarzania siły.

Cel programu praktycznego, prezentowany przez autora dzieła Świat powojenny i Polska, to rozwój i postęp oraz dążenie do dobrobytu materialnego ${ }^{23}$. Roman Dmowski podkreślał jednocześnie, że kapitał, który pozostał Polakom nie pozwala na rozwój. W związku z tym nakazał zerwanie z programem powolnego zmniejszania możliwości Polski. Uznał, iż należy budzić w społeczeństwie energię polityczną, a przede wszystkim świadomość. Miało się to dokonać przez akty

\footnotetext{
20 R. Dmowski, Nasz patriotyzm, dz. cyt., s. 49-5I.

2 I R. Dmowski, Nasz patriotyzm, dz. cyt., s. 55.

22 R. Dmowski, Nasz patriotyzm, dz. cyt., s. 57.

23 R. Dmowski, Nasz patriotyzm, dz. cyt., s. 58-6o.
} 
walki, do jakich zaliczone zostały m.in. niepłacenie podatków, niepodejmowanie pracy. Rzeczywistość miała pokazać, jak daleko należy posunąć się w środkach walki tego typu. Jednocześnie myśliciel zalecił czuwanie nad rozwojem, a także obronę interesu klas, których podniesienie standardu życia i dobrobyt jest korzyścią całego narodu. Widać tu zerwanie z etyką słuszności, typową dla myślicieli romantycznych, polegającą na czynieniu tego, co właściwe, wzniosłe i piękne. Poglądy te charakteryzują się etyką odpowiedzialności za skutki, wyzbyciem się moralności w sferze międzynarodowej oraz przywiązaniem do rzeczy materialnych.

W kolejnym dziele Myśli nowoczesnego Polaka z 1902 roku, Dmowski powtarza założenia spójności narodu ${ }^{24}$. Stanowi on, zdaniem myśliciela, organiczną jedność. Dodał, że czasy szlachty i arystokracji bezpowrotnie minęły. W związku z tym sprzeciwia się w tym aspekcie walce klasowej i zaleca dążenie do odwiedzenia robotników od ideologii socjalistycznej. O interes Polski mają walczyć ziemianie, wielcy przedsiębiorcy, drobnomieszczaństwo i rolnicy tak, aby osiągnąć państwo narodowe zgodne z polską tradycją oraz szanujące idee wolności i własności. Własność prywatna musi być używana zgodnie z interesem ludności całego kraju. Wolność jednostki nie może zamienić się w indywidualistyczny egoizm sprzeczny z interesami rodziny i narodu. Widać tu podkreślenie roli tradycji i wychowania w określonych instytucjach, trzymających w karbach społeczeństwo oraz znowu istotność kultury materialnej.

W omawianym dziele jest widoczne, że istotne są siły twórcze rasy i tradycji oraz pełna świadomość swojej tożsamości. Dmowski podkreśla rolę życia zbiorowego, promując etykę dumy z narodu. Zauważa, że rodząc się, człowiek wkracza i dostosowuje się do gotowych form i gotowej organizacji narodu. Formy te i organizacja są wynikiem pracy długiego szeregu pokoleń, które tworzyły, budowały, uzupełniały i wreszcie poprawiały to, co było złego. Ważnym elementem jest

24 R. Dmowski, Charakter narodowy, w: R. Dmowski, Myśl nowoczesnego Polaka, wprow. N. Tomczyk, Wrocław 2002, s. 32-39. 
ukazanie etyki konieczności wkładu w cywilizację i rozwój narodu. W przemyśleniach Dmowskiego można dostrzec istotność osadzenia analizy w określonych warunkach oraz uznanie człowieka za podmiot działający i aktywny ${ }^{25}$.

Należy także przedstawić teorię patriotyzmu. Jest on uznany za stosunek moralny jednostki do społeczeństwa. U Dmowskiego priorytetem jest budowanie silnego narodu bez względu na jego sytuację. Siłę narodu definiował jako jego siłę moralną, przejawiającą się w żądzy szerokiego życia, chęci pomnożenia narodowego dorobku i posiadaniu wpływu oraz gotowości do poświęceń dla urzeczywistnienia narodowych celów ${ }^{26}$. Patrząc w ten sposób, dostrzec można ideę budowania potężnego społeczeństwa, typową dla realistów politycznych.

Ponadto, zdaniem Dmowskiego, możliwości ekonomiczne, które posiada Polska, nie są wykorzystywane przez właściwe grupy, lecz przez Niemców i Żydów. Stwierdził jednak, że osiagany w ten sposób dobrobyt, pozwala na wytworzenie dobrego typu Polaka - czynnego, przedsiębiorczego, o mentalności zdobywcy. Typ ten jest jednak pozbawiony wartości politycznej. Uwaga ta potwierdza, że realizacja interesu własnego narodu powinna odbywać się nawet kosztem pozostałych.

Ostatnim dziełem, nad którym prezentowana analiza będzie się skupiać, jest zatytułowana Niemcy, Rosja i kwestia Polska i przedstawia położenie polityczne Polski i jej zaborców. Głównym celem publikacji było wykazanie największego zagrożenia dla Polaków, jaki stanowiły Prusy i ich polityka germanizacji, doprowadzająca do proletaryzacji narodu polskiego ${ }^{27}$. Po drugie, Dmowski zaznaczał, iż dla Prus kwestia istnienia państwa polskiego była sprawą być albo nie być Prus. Ponadto tereny zagarnięte przez Prusy należało rozpatrywać

25 R. Dmowski, Podstawy etyczne, w: R. Dmowski, Myśl nowoczesnego Polaka, dz. cyt., s. 99-103.

26 R. Dmowski, Oszczędność sit i ekspansja, w: R. Dmowski, Myśl nowoczesnego Polaka, dz. cyt., s. 64-70.

27 R. Dmowski, Niemcy, Rosja i kwestia Polska, posł. N. Tomczyk, Wrocław 2002 . 
jako kolebkę państwowości Polski i dostrzegać jej szczególną wartość. Myśliciel tym samym podkreśla konieczność nierezygnowania $\mathrm{z}$ wytworów cywilizacyjnych oraz ciągłego ich pogłębiania. Za cel państwa uznaje przetrwanie.

Dmowski wskazywał, że dla Rosji i Austrii kwestia polska była wyłącznie problemem lokalnym, podczas gdy dla Niemiec - zasadniczą sprawą powiązaną z ich ekspansją w kierunku wschodnim. Z tego względu polityk uważał, że Niemcy będą podejmować próby, aby podjąć współpracę z Rosją przeciw Polsce. Dmowski przewidywał mechanizm racjonalnej kalkulacji państw na arenie międzynarodowej.

Istotne jest także, że myśliciel zaprezentował pogląd, iż Rosja umożliwia polityczne zjednoczenie narodu polskiego ${ }^{28}$. Zaznaczył jednocześnie, że „rozwiązanie kwestii polskiej leży w rękach Rosji” ${ }^{29}$. Dmowski dostrzegł słabości Rosji w porównaniu z analizą polityki pruskiej i zalecał postawę prorosyjską, gdyż umożliwiała ona większe zyski społeczne i polityczne.

\section{Zakończenie}

Przedstawiona analiza wskazuje, jak głęboki jest związek poglądów Romana Dmowskiego z założeniami paradygmatu realizmu politycznego. Po odzyskaniu przez Polskę niepodległości, część wizji myśliciela uległo przeformułowaniu. Nie należy jednak zapominać, iż przed tym wydarzeniem podkreślał, iż Polacy, tak jak inne narody, mają do odegrania własną misję cywilizacyjną, co nawiązuje do romantyzmu politycznego. Jednocześnie piętnował wady polskie, takie jak bierność, lenistwo, niezdolność do pracy zbiorowej czy niezdyscyplinowanie. Pozostawał krytyczny wobec chrześcijaństwa, którego normy moralne

\footnotetext{
28 R. Dmowski, Niemcy, Rosja i kwestia Polska, dz. cyt., s. I06-I Io.

29 Podkreślił również, że to Rosja jest decydującym podmiotem w sprawie polskiej.
} 
uważał za sprzeczne z założeniami i potrzebami $z$ drowego, narodowego egoizmu. Skłaniał się w większej mierze do podporządkowania religii interesom państwa lub narodu na wzór protestantyzmu w wydaniu niemieckim lub angielskim. Jednakże podzielał antysemickie poglądy ówczesnego Kościoła katolickiego, widząc Żydów jako podstawę spisku antykatolickiego z udziałem komunistów, socjalistów, liberałów, masonów i protestantów ${ }^{30}$. Uważał Żydów za sprzyjających Niemcom wrogów Polski, element niepewny i niepożądany w społeczeństwie. Dmowski sprzeciwiał się ich asymilacji i zwracał uwagę na brak chęci do asymilacji ze strony mniejszości. Przekładało się to jego zdaniem na nieumiejętność realizacji interesu narodowego oraz skuteczność ekonomiczną, odbierającą możliwości Polakom.

Oczywiście nie można uznać, że Roman Dmowski prezentował poglądy zgodne wyłącznie z realizmem politycznym, lecz spójność tego paradygmatu z jego myślą jest zaskakująco zbieżna.

Ponadto nie tylko poglądy, ale także działania polityczne autora publikacji Polityka polska i odbudowanie państwa wskazywały na pokrewność z prezentowanym nurtem. Należy do nich zaliczyć głoszenie szerokiego sprzeciwu wobec działań antyrosyjskich, przedstawienie programu autonomii Królestwa Polskiego, zalecenie inkorporacyjnej koncepcji wschodniej granicy Polski oraz bycie posłem Dumy rosyjskiej.

\section{Streszczenie}

REALIZM POLITYCZNY ROMANA DMOWSKIEGO

Artykuł poświęcony jest Romanowi Dmowskiemu, jego twórczości i poglądom politycznym, w szczególności realizmowi politycznemu działacza. W pierwszej części zostały przedstawione same założenia paradygmatu realizmu politycznego, które następnie zostały zestawione

30 Por. K. Kawalec, Roman Dmowski..., dz. cyt. 
z poglądami Dmowskiego, wynikającymi z jego dzieł. Wyznaczone ramy czasowe to okres twórczości Dmowskiego do odzyskania przez Polskę niepodległości.

\section{Summary}

ROMAN DMOWSKI'S POLITICAL REALISM

The scientific paper is on Roman Dmowski, his pieces of work and his political views, in particular his political realism. The first part presents the foundations of the political realism paradigm, then compared with Dmowski's views arising from his works. The time frame of the scientific paper is the period of Dmoski's work until Poland regains independence.

\section{Bibliografia}

Dmowski R., Myśl nowoczesnego Polaka, wprow. N. Tomczyk, Wrocław 2002.

Dmowski R., Niemcy, Rosja i kwestia Polska, posł. N. Tomczyk, Wroclaw 2002.

Dmowski R., Wybór pism, wybór i wstęp R. Wapiński, Warszawa 1990.

Hobbes T., Lewiatan, czyli materia, forma i wtadza państwa kościelnego i świeckiego, przeł. Cz. Znamierowski, Warszawa 1954.

Machiavelli N., Wybór pism, przeł. J. Gałuszka i in., Warszawa 1972.

Hume D., Badania dotyczące rozumu ludzkiego, przeł. J. Łukasiewicz, K. Twardowski, Warszawa 200I.

Kawalec K., Roman Dmowski. Biografia, Poznań 2016.

Kawalec K., Spadkobiercy niepokornych: dzieje polskiej myśli politycznej I918-1939, Wrocław 2000.

Kimla P., Historycy-politycy jako źródto realizmu politycznego, Kraków 2009. 
Mearsheimer J., The tragedy of great power politics, Londyn 200I;

Morgenthau H. J., Polityka między narodami. Walka o potęge i pokój, przeł. R. Włoch, Warszawa 20 Io. 